\title{
Corona Virus and Education Crisis in Kenya: Lessons Learnt
}

\author{
Robert Bisonga Mwebi
}

\section{ABSTRACT}

\begin{abstract}
Since the emergence of COVID pandemic, the education sector seems to have been worst hit due to closure of all learning institutions worldwide, as a way of containing the spread of the disease. Consequently, most institutions have adopted remote learning as an alternative to offering education to the learners. However, a myriad of challenges has ensured that threatens the attainment of SDG goal number 4 on quality of education. This paper attempts to discuss the challenges that are facing online education in Kenya and its likelihood of propagating traditional social inequalities that threatens the attainment of sustainable development goal on quality education. The paper recommends the need to come up with a policy to ensure harmony in the way e-learning is conducted to enhance quality, equity, and access to educational opportunities for all learners in Kenya.
\end{abstract}

Keywords: Access; Education; Equity; Quality.
Published Online: July 20, 2021

ISSN: $2736-4534$

DOI :10.24018/ejedu.2021.2.3.99

\section{R. B. Mwebi*}

Department of Curriculum and Education Management, Laikipia University, Kenya.

(e-mail: rmwebi@laikipia.ac.ke)

*Corresponding Author

\section{INTRODUCTION}

Though the impact of the Corona virus disease popularly known as COVID-19 in Kenya is yet to be documented, its effects on the economy, education and the general livelihoods of the people cannot be gainsaid. From the time of its emergence in late December 2019, the disease evolved into a pandemic and within a span of three months it had reached every corner of the world, heavily affecting economies of most countries; threatening livelihoods and consequently putting the healthcare systems of most nations both developed and developing in limbo. According to [19] over 32 million people worldwide have been infected by the virus with nearly one million people succumbing to the disease as of $24^{\text {th }}$ September 2020. Health care systems have been strained substantially and economies have been affected as evidenced in the significant reductions in incomes of people, a rise in unemployment, and disruptions in the transportation, service, and manufacturing industries [1].

Education is one of the sectors that has been heavily affected by the disease as it has led to closure of schools and other educational institutions around the globe. UNESCO estimates that close to 1.3 billion learners, representing ninety-one (91) percent of the learners worldwide are unable to go to school or university, as a result of measures put in place to contain the disease [2]. Kenya reported its first case of corona virus (COVID-19) in March 13, 2020. Immediately thereafter, the government put in place measures aimed at mitigating and containing the spread of the virus. Among these measures included the closure of schools, universities, and other learning institutions in the country. By the time of school closure, Kenya had joined about 107 countries in the world that had implemented national school closures as a result of COVID-19 [4]. Empirical evidence demonstrates that school closure during epidemics helps reduce the chain of transmission of diseases and therefore potentially lowers the spread of the disease [5]. In line with this observation, the current cabinet secretary for education in Kenya Prof. George Magoha while addressing the nation on the way forward for education sector in the country, said that all learning institutions shall remain closed till 2021. Further he encouraged institutions of higher learning to offer virtual teaching services to their students.

To mitigate the effects of school closure on education in Kenya, the Ministry of Education (MOE) through the Kenya Institute of Curriculum Development (KICD) started offering online classes to primary and secondary school learners through radio programmes (KCB English service and Radio Taifa), TV channels (Edu Tv and You tube Tv channels), and the Kenya education cloud for interactive lessons. Besides, many players came on board to partner with the government agency in providing online learning platforms as a way of reaching out to the learners. Among these players included Star-Times TV, Safaricom, Viusasa and many other mobile application apps that have been developed to enable learners' study from home [6]. In addition, publishers such as Longhorn offered their digital content for free with the aim of ensuring learning continuity [7]. This scenario has been replicated in most African countries whereby key education stakeholders have instituted measures to promote the continuity of education from home such as offering classes on national TVs and radio stations as is the case in Côte d'Ivoire and Kenya and using online resource platform as is the case with Senegal and South 
Africa among other African countries [2]. These efforts by African countries are in line with UNESCO's call for investment in remote learning in the wake of school closure to mitigate the disruption of learning caused by the disease [3].

Whereas online education is seen as a stop gap measure to provide education and engage learners during the period of school closure, efforts to make it achieve its intended goal have however been faced with challenges which tend to threaten the learning processes amid the pandemic. For example, a feature appearing on the Citizen TV on $3^{\text {rd }}$ August 2020 evening news revealed that; about 120 private schools have been closed, some of which are likely not to resume in 2021 when schools are supposed to re-open. The reported challenges were cited as operational financial constraints emanating from failure to pay fees by parents and inability to repay loans, where in some cases school facilities and equipment including vehicles for school transport were auctioned to recover unpaid loans. Education sector stakeholders agree that there is need to come up with innovative ideas to help the learning process to continue so that learners, especially those to be examined through national examinations by end of 2021, can cover the syllabus. However, there is a bone of contention between the MOE technocrats and the other stakeholders in the education sector. While the MOE on one hand contends that online education is the only way to go in order to cover the syllabus for students to be examined during end of cycle summative examinations, parents, community leaders and trade unions on the other hand see the ministry's intervention as discriminatory. The main argument is that not all learners are able to access online education given that it is disseminated through media such as radio, television and smart phones all of which require internet connectivity, but which most parents especially in rural areas and urban informal settlements cannot afford or is non-existent in some areas.

This paper therefore is an attempt to discuss the effect of online education on the attainment of the principles of access, equity and quality of education as enshrined in the SDGs, the Kenyan Constitution, and the Basic Education Act. The paper also explores the challenges facing the online education platforms and outlines recommendations for adoption by the basic education institutions to ensure learning continuity in case of future eventualities that can affect the education sector.

\section{ONLINE LEARNING ACCESS, EQUITY AND QUALITY OF EDUCATION}

In as much as the online education is an innovative way of cushioning learners under the current COVID-19 circumstances, it is imperative to note that its provision should carefully be thought out in line with the sustainable development goals (SDGs) and the national agenda on education and development. The current framework by the Kenya Institute of Curriculum Development (KICD) in providing education remotely via online learning platforms poses a great hindrance towards the attainment of the global SDG goal number 4 regarding quality education, equity and access to educational opportunities as enshrined in both the Kenyan Constitution [8] and the Basic Education Act [9]. The effect of this initiative on educational quality, access and equity are discussed hereunder.

\section{A. Quality of Education}

It is worth noting that the SDG goal number four (4) on quality of education underscores the need to ensure inclusive and equitable quality education and promote lifelong learning opportunities for all. Inclusion in this case means setting basic minimum standards for education that is shared by all students regardless of background, personal characteristics, or location [10]. This in essence implies that learners should not be discriminated irrespective of race, gender, or socio-economic background. The provision of education via online platforms as is in the current case contravenes this call in the sense that, the online platform does not involve all the learners considering the digital divide existing across the Kenyan population. This implies that education is only accessible to those who can afford to own and use the educational media such as radio, television sets and computers or mobile phones with internet connectivity while excluding those who cannot afford. Empirical evidence shows that less than half of the population in Kenya do not own the electronic gadgets that the KICD uses to transmit educational information [11]. This observation implies that majority of the learners from poor households are excluded from the education system which goes against the bill of rights on education of a child as contained in the Kenyan Constitution of 2010. The bill of rights confers to every child the right of quality education. From the foregoing, it implies that provision of online education denies some learners an opportunity to enjoy their inalienable right just because they cannot afford the ICT equipment used as the medium for transmitting education content. A study by [3] indicates that approximately 263 million children and youth worldwide are not in school with sub-Saharan Africa mostly affected by the highest rates of exclusion. The report further contends that 65 of the poorest children for every 100 of the richest go to school in sub-Saharan Africa [12]. On the same note, in Kenya, more than 1.2 million primary-school-age children do not attend school [18]. From the foregoing, it means that should education continue to be offered based on the online platform, the problem of exclusion will be exacerbated, and more children will be excluded from the education system thus negating the gains made thus far since the advent of free primary and secondary education in Kenya.

\section{B. Equity in Education}

Equity requires putting systems in place to ensure that every child has an equal chance for success. The Organization for Economic Co-operation and Development (OECD) defines equity in education as fairness, which means ensuring that personal and social circumstances do not prevent students from achieving their academic potential [10]. Given that some learners in Kenya have no access to internet connectivity, online education therefore denies learners from poor households the opportunities that the affluent children have access to. This kind of education will therefore tend to create clusters of learners within the school system i.e. the haves and have-nots. This form of education provision will therefore maintain and even reinforce existing social inequalities and the monopolies of social 
status through online education [12]. Ideally, education is supposed to bring equality in the society by providing children with equal opportunities for learning and social participation which may not be the case as technological infrastructure tends to be unequally distributed. The clamour for a just and egalitarian society therefore becomes a pipe dream especially for students from poor households who do not have the appropriate technological infrastructure.

\section{Access to Education}

Since 2003, when the Kenyan government declared free and compulsory education in light of education for all global initiative [13], Kenya has made significant strides towards increasing access to educational opportunities particularly through the free primary and free day secondary education initiatives. However, according to the ministry of education's national education sector strategic plan of 2018-2022, there are a number of constraints hindering access to primary education such as direct costs on uniforms and school meals; indirect costs; poverty; insecurity; long distances covered to schools; as well as lack of food and water at home [13]. This therefore means that the online education platform adds to the list of those constraints which are likely to face many more children from low socio-economic backgrounds, urban informal settlements, and those in ASAL areas, including refugee camps from accessing education opportunities. In most of these households, owning an ICT gadget is a luxury as their most immediate needs to contend with include access to food and shelter. For these children therefore, owning ICT equipment or getting internet connectivity for education dissemination is a secondary option as they live from hand to mouth. This makes access to online education somewhat difficult thus denying majority of learners' access to education.

\section{Challenges OF ONLINE EdUCATION IN KENYA}

Education is acknowledged as a means for transforming and empowering communities through acquisition of skills, knowledge, and attitudes to enable learners to become productive members of the society. Even though online education was introduced by the Kenya government in 2020 to ensure learning continuity amid the coronavirus disease, the mode seems to face a variety of challenges in its implementation. One of the challenges to online education in most of the African countries is poor technological infrastructure to support remote learning. According to [17], African countries rank at the bottom third of countries in terms of internet conectivity and affordability thus making online instruction a mirage. Efforts by the MOE in Kenya to provide learning using the e-learning platforms mentioned herein seem to have attracted a lot of public furors with most education stakeholders holding the view that online classes are a waste of time [14]. Indeed, the provision of online learning in Kenya can be considered a farfetched adventure although the efforts made towards this end need to be lauded. Access and use of basic ICT media upon which the online content is disseminated is one of the problems that the current online education by KICD faces. Evidence from various government agencies shows glaring disparities across the households in terms of use and ownership of ICT media namely mobile phones, radios, television sets and computers. For instance, the national ICT survey report of 2010 revealed that $33.1 \%$ household members aged above three years owned a radio, $18.2 \%$ owned a computer, $15.0 \%$ of households owned a Television (TV) set and $7.4 \%$ had internet connectivity [11]. Similarly, the 2015/2016 Kenya Integrated Household Budget Survey (KIHBS), shows that $9.5 \%$ the population use computers while $16.6 \%$ of the population aged 3 years and above use internet whereas 8 out of every 10 persons use radio; and only about 7 out of 10 people used mobile phones. The study further revealed that there was wide variation in the use of ICT equipment and services in both rural and urban areas, with urban areas consistently having higher proportions of population using ICT equipment and services. Moreover, the report revealed notable variations in the proportion of population using ICT equipment and services across urban and rural areas [15]. Furthermore, the Kenya Housing and Population Census (KHPC) report of 2019 indicates that $22.6 \%$ of individuals aged 3 years and above use the internet while $10.4 \%$ use a computer. Regarding ownership of ICT gadgets, the report indicates that 20.6 million (43\%) of individuals aged 3 years and above own a mobile phone, whereas $40.7 \%$ of households in Kenya own a television set [16].

Clearly, the reports from the mentioned government agencies paint a stark reality of the actual situation in most of the Kenyan households. There is no doubt that there is a glaring digital divide which mirrors the existing traditional social inequalities. This implies that majority of the households cannot afford to use and/or own the ICT equipment which are used as a basic medium for online education transmission, thus marginalizing children coming from poor households and those in places where internet connectivity has not penetrated. It is therefore difficult for online education to effectively be undertaken with an aim of reaching all the learners in an environment where there is unequal distribution of ICT facilities, and resources coupled with poor internet connectivity and inadequate infrastructural development in technology. The promise of ICT in educational institutions is the potential for increased access, improved quality, and efficiency. The paper therefore recommends that there is need to come up with a policy to ensure that there is harmony in the way e-learning is conducted to ensure equity and access for learners in Kenya. To ensure effectiveness, all stakeholders should work together to produce relevant materials and provide avenues for sharing limited e-learning resources and skills particularly among children from poor backgrounds.

\section{REFERENCES}

[1] A. Pak, O. A. Adegboye, A. I. Adekunle, K. M. Rahman, E. S. McBryde and D. P. Eisen, "Economic Consequences of the COVID-19 Outbreak: the Need for Epidemic Preparedness," Frontiers in Public Health, 29 May 2020.

[2] L. Nyariki and S. D. Cupis, "Africa supports reading and learning during the COVID-19 pandemic," 23 April 2020. [Online]. Available: https://www.globalpartnership.org/blog/africasupports-reading-and-learning-during-covid-19-pandemic.

[3] UNESCO, "Global Education Colalition: Covid-19 Education response," $2020 . \quad$ [Online]. Available: https://en.unesco.org/covid19/educationresponse/globalcoalition. 
[4] M. V. Russell, S. J. Russell, H. Croker, J. Packer, J. Ward, C. Stansfield, O. Mytton, C. Bonell and R. Booy, "School closure and management practices during coronavirus outbreaks including COVID-19: a rapid systematic review," Lancet Child Adolesc Health, pp. 397-404, 2020.

[5] D. L. Giancarlo, V. K. Kim, C. Pietro, P. Chiara, B. Nathalie, H. Niel and C. Vittoria, "The impact of regular school closure on seasonal influenza epidemics: a data-driven spatial transmission model for Belgium," BMC Infectious Diseases, pp. 18-29, 2018.

[6] B. Khaduli, "KICD Partners with startimes to enable Students Access Online Learning," Kenya News Agency, 14 May 2020.

[7] Longhorn, "Longhorn Digital," 2020. [Online]. Available: https://longhornpublishers.com/longhorn-digital/. [Accessed 15 May 2020].

[8] Republic of Kenya, "The Kenya Constitution," Government Printer, Nairobi, 2010.

[9] Republic of Kenya, "The basic education act," Government printer, Nairobi, 2013.

[10] OECD, "Ten Steps to Equity in Education," Author, Paris, 2008.

[11] Communication Commision of Kenya, "National ICT Survey Report," Author, Nairobi, 2010.

[12] S. Schwartzman, C. Spiel and S. Verma, "Can education become truly egalitarian worldwide?," The Conversation, 20 February 2018.

[13] Ministry of Education, "National Education Sector Strategic Plan for the Period 2018 - 2022," Government Printer, Nairobi, 2018.

[14] R. Nyaguthie, "Kenyans say online learning by education ministry is waste of time," Tuko News, p. 20, Monday April 2020.

[15] Kenya National Bureau of statistics ( KNBS), "2015/2016 Kenya Integrated Budget Household Survey," KNBS, Nairobi, 2018.

[16] F. Sunday, "Internet access in Kenya," The Standard Newspaper, Nairobi, 2020

[17] C. J. Thomas, "Education Plus Development," 13 April 2020 [Online]. Available: https://www.brookings.edu/blog/educationplus-development/2020/04/13/coronavirus-and-challengingtimes-for-education-in-developing-countries/.

[18] UNICEF- KENYA, "Quality Education: Providing inclusive and equitable quality education for every child in Kenya," Author, Nairobi, 2012.

[19] World Health Organisation, "WHO Coronavirus Disease (COVID19) Dashboard," 24 September 2020. [Online]. Available: https://covid19. who.int/?gclid=EAIaIQobChMIhbGw5JmC7AIV CIXVCh1G_QHSEAAYASAAEgJCyPD_BwE.

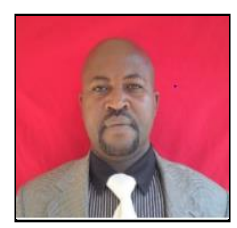

Dr Robert Bisonga Mwebi was born in 1978 in Nyamira County- Kenya. He completed his bachelor degree in Education with first class honours from Egerton University in 2001. He was awarded a scholarship through the Ministry of Education in Kenya under the Indo- Kenya cultural exchange programme to pursue a master of education degree from Pune University in India. He has a Master of Business Administration Degree and PhD in Teacher Education from Pune University.

Currently he works at Laikipia University as the Director in charge of Quality Assurance and Standards and a Senior Lecturer in the Department of Curriculum and Education Management of Laikipia University. He has trained as a Job Analyst by Price Waterhouse Coopers (2016) and Kenya School of Government (2020). He is also an expert in tracer studies as well as monitoring and evaluation expert of projects and programmes. He is a lead auditor in QMS and ISMS based on ISO 9001:2015 and ISO/IEC 27001:2013 respectively. For a couple of years, Dr Mwebi has been involved in reviewing curriculum for various organizations and universities and preparing policies and policy briefs based on outcomes of research findings. Dr Mwebi has trained for various organizations both in the private and public sector such as: Danish Refugee Council, Care International -Kenya, The Commission for Administration of Justice (the Ombudsman- Kenya), International Organization for Migration (IOM), KEPSA/World Bank (KYEP), public and private universities. Some of the areas he trains in are: Social Entrepreneurship, Proposal Writing, Strategic Management, Participatory Monitoring \& Evaluation of Projects, Project Management, Leadership and Governance as well as Resource Mobilization.

Dr Mwebi is a member of the East African Quality Assurance Network and the Kenya Universities Quality Assurance Network. He has served as a member of various committees such as the Board of Postgraduate Studies; Policy Development and Review, COVID 19 mitigation, Promotion and review committee, and the Career Establishment committee among others. He is an external examiner for various universities and has supervised several Masters and $\mathrm{PhD}$ student. He has published intensively in the area of higher education. His research interests are in the areas of Curriculum Studies, Teacher Education and Monitoring \& Evaluation. Dr Mwebi is a motivated, energetic, and outgoing individual with strengths in Training Needs Analysis, Research Methods, Applied Statistics, and data analysis. 